Original Article

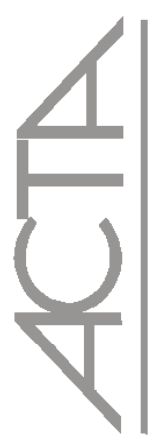

\title{
Universal isolation precautions for patients at an academic hospital*
}

\author{
Precauções universais em isolamentos de pacientes em hospital universitário \\ Precauciones universales en el aislamiento de pacientes en un hospital universitario
}

\author{
Vanessa Gomes Maziero', Marli Terezinha Oliveira Vannuchi², Dagmar \\ Willamourius Vituri ${ }^{3}$, Maria do Carmo Lourenço Haddad ${ }^{4}$, Cristiane Nakaya Tada ${ }^{5}$
}

\begin{abstract}
Objective: To apply universal isolation precautions for patients at an academic hospital by a nursing team. Methods: This descriptive and prospective study used data from advice service of quality control and nursing care that were gathered in observational reports of universal isolation precautions for patients admitted in two surgical inpatient units during 2008 and 2010. Results: The mean general classification for both units was between desirable and adequate in the observational analysis of universal precaution. A borderline effect was observed only in November 2008 at the Men's Surgical Unit. The units assessed had compromised biosecurity, however, as time advanced data showed an improvement on their performance. Conclusion: The effective involvement of nurses in the unit is critical to prevent and control nosocomial infections. Keywords: Communicable disease control; Universal precautions; Patient isolation
\end{abstract}

\section{RESUMO}

Objetivo: Utilizar as precauções universais pela equipe de Enfermagem em isolamento de pacientes em Hospital Universitário. Métodos: Estudo descritivo, prospectivo. Foram utilizados dados da Assessoria de Controle de Qualidade da Assistência de Enfermagem, correspondentes aos relatórios das observações das precauções universais em isolamento de pacientes em duas unidades de internação Médica - Cirúrgica, no período entre 2008 e 2010. Resultados: As duas unidades da instituição apresentaram média geral de classificação, da análise observacional de precaução universal, entre desejável e adequada, sendo limítrofe apenas em novembro de 2008 na unidade Médica-Cirúrgica Masculina. As unidades avaliadas, quanto à adesão às precauções universais, apresentaram comprometimento com biossegurança, e os dados exibidos mostraram-se melhores a cada ano descrito. Conclusão: A participação ativa do enfermeiro responsável pela unidade é importante na prevenção e controle de infecções hospitalares.

Descritores: Controle de doenças transmissíveis; Precauções universais; Isolamento de pacientes

\section{RESUMEN}

Objetivo: Utilización de las precauciones universales por el equipo de Enfermería en el aislamiento de pacientes en un Hospital Universitario. Métodos: Estudio descriptivo, prospectivo. Fueron utilizados datos de la Asesoría de Control de Calidad de la Asistencia de Enfermería, correspondientes a los informes de las observaciones respecto a las precauciones universales en el aislamiento de pacientes en dos unidades de internamiento Médico - Quirúrgico, en el período comprendido entre 2008 y 2010. Resultados: Las dos unidades de la institución presentaron un promedio general de clasificación, del análisis observacional de precaución universal, entre deseable y adecuada, siendo limítrofe apenas en noviembre del 2008 en la unidad Médico-Quirúrgica Masculina. Las unidades evaluadas, respecto a la adhesión a las precauciones universales, presentaron compromiso con la bioseguridad, y los datos exhibidos se mostraron mejores en cada año descrito. Conclusión: La participación activa del enfermero responsable por la unidad es importante en la prevención y control de infecciones hospitalarias.

Descriptores: Control de enfermedades transmisibles; Precauciones universales; Aislamiento de pacientes

\footnotetext{
* This study was adapted from a final paper in nursing care management service entitled "Universal isolation precautions on patients at an academic hospital" - Universidade Estadual de Londrina - UEL - Londrina (PR), Brazil.

${ }^{1,5}$ Registered nurse. Universidade Estadual de Londrina - UEL - Londrina (PR), Brazil.

2,4 Associate professor. Universidade Estadual de Londrina - UEL - Londrina (PR), Brazil.

${ }^{3}$ Master degree. Universidade Estadual de Londrina - UEL - Londrina (PR), Brazil.
} 


\section{INTRODUCTION}

Nosocomial infections are infections that are acquired after patient admission. They can develop during the inpatient period or after discharge, and are often related to procedures performed during hospitalization according to the Ordinance n. ${ }^{\circ} 2.616$ May $12,1998^{(1,2)}$. Such infections increase morbidity and mortality rates, time of hospital stay, occupation rates and costs of treatment ${ }^{(1)}$.

The history of nosocomial infection must recognize Semmelweis, who in 1847 introduced hand washing to all physicians and medical and nursing students to reduce maternal mortality due to puerperal fever. Another important name is Joseph Lister, who in 1865 invested in hand washing and sanitization of instruments and surgical sites to decrease the rate of infection in his surgeries ${ }^{(1)}$.

In the nursing field, prevention and control of nosocomial infections in hospital environments appeared in the 19th century with Florence Nightingale, who used individualized care through patient isolation and fewer beds in wards, among others actions. Florence Nightingale was responsible for transforming indexes of infectious agent transmissions. Her actions helped to reduce mortality rates and also brought management initiatives through nursing knowledge $e^{(1,3)}$.

The first intervention by the Brazilian governmental to control nosocomial infections was the issue of Ordinance $\mathrm{n}^{\circ} 196$ June 24, 1983, by Ministry of Health, which established that "all hospitals in the country must have a nosocomial infection control committee (NICC) no matter the nature of the financial institution". After that, an infection control manual was created that still serves today as the main reference for Brazilian hospitals and contains guidelines to regulate committee activities, and criteria to identify and diagnosis different types of nosocomial infections ${ }^{(1,4)}$.

Extrinsically acquired nosocomial infection are related to surfaces, equipment and medical and hospital devices used in invasive procedures and for patient care. Such infections could be prevented by means such as control of pathogens, asepsis measures, adequate treatment of materials and contaminated environment. It is important to highlight that, above all, in the actions of each professional involved in delivering patient care are critical to maintain god prevention practices, control, and information on the nosocomial infections ${ }^{(1)}$.

In the last years the following changes occurred after the NICC creation: the use of personal protective equipment (PPE), biological control for microorganism on surfaces and hospital materials by cleaning, sanitizing and/or sterilizing. In addition, isolating measures such as universal precautions and precautions by route of transmission (air, droplet and contact) are important ${ }^{(5)}$.

Universal precautions, also named as basics or standards, are procedures that must be established at health institutions and applied to all patients with an infectious process or if contamination is suspected to reduce the risks of cross-contamination among environment, patients and health care professionals. Some examples of universal precautions are hand washing before and after any procedure, use of gloves, aprons, masks, etc ${ }^{(5,6)}$.

This relevance of universal precautions is especially clear for the quality of care and safety of hospitalized patient affected by nosocomial infection. Because of this importance, we conducted this study to evaluate universal precautions adopted by a nursing team for patients cared for in isolation at an academic hospital. Evaluative measures work as tools to improve known potential problems and fragile internal processes. In addition, they support the creation of strategies to deal with identified problems.

This study presents evidence on quality of care delivery for patients who required universal precautions, as well as to motivate and support the development of additional research on the subject.

\section{METHODS}

This descriptive and prospective study used a quantitative approach and was carried out at an academic hospital of high complexity with 312 beds in north of Parana State. This hospital is part of the Brazilian public health system (SUS, acronym in Portuguese) and serves patients at both the outpatient and inpatient level in several medical specialty areas.

Data were collected from the database of advice service of quality control and nursing care (ASQNC) that is coordinated by the Nursing Board of Director who is responsible for evaluating the quality of nursing care delivery to patients in hospital units.

The material used in the study came from results of operational auditing of nursing care regarding the use of universal precautions on isolated patients at men's and women's surgical unit with 64 and 47 beds, respectively. Data were collected during 2008, 2009 and 2010 by trainees in the third and fourth year of nursing undergraduate program. Each trainee received instruction and was followed-up by the nurse responsible for ASQNC.

Questionnaires had 39 items on quality standards, implemented or not. Answers options were yes, no or not applicable. The instrument was subdivided into four areas: 1) personal presentation, 2) use of PPE, 3) adequate isolation and patient care with multiresistant infection (MI) and 4) adequate isolation and patient care with infectious disease or that need reverse isolation. 
We observed in 1) - personal presentation covered the following: tied up hair, short nails, use of uniform by employees, adequate use of scrub uniform, wearing jewelry; in 2) - use of PPE was checked if it was adequate or not; in 3) - adequate isolation and patient care with multiresistant infection, the presence of Enterococcus resistant to vancomycin and isolations of patients with infectious diseases or reserve isolation. The following items were noted: if rooms/beds were labeled adequate; if PPEs was available and adequate; if employees changed their gloves in every instance; if employees washed their hands frequently; if rooms/wards were organized and cleaned; if disposal were adequate, among others.

Care quality was classified on a proportion scale adapted from the Haddad and Evora model $(2008)^{(7)}$. In this scale, care was classified as "safety" when $100 \%$ items were correct, "adequate" when items were between 90-99\%, "desired" if between 80-89\%, "borderline" if between $70-79 \%$, and "insufficient" when corrected items were lower than $70 \%$.

This study was approved by the Research and Ethical Committee of the National System of Information on Research Ethics (SISNEP, acronym in Portuguese), registered in CAAE $n^{\circ}$ 0208.0.268.000-11.

\section{RESULTS}

The comparative analysis of observation of universal precautions as shown in table 1 presents a percentage mean of all items, that is, the general performance in the women `s surgical unit during October and November 2008, May and November of 2009 and April of 2010.

Table 1. Comparative analysis of observation of universal precautions in women`s unit during October and November 2008, May and November 2009 and April 2010. Londrina, PR

\begin{tabular}{|c|c|c|c|c|c|}
\hline & \multicolumn{2}{|c|}{2008} & \multicolumn{2}{|c|}{2009} & \multirow{2}{*}{$\begin{array}{l}2010 \\
\text { April } \\
\text { n(\%) }\end{array}$} \\
\hline Universal precautions & $\begin{array}{c}\text { October } \\
\mathrm{n}(\%)\end{array}$ & $\begin{array}{c}\text { November } \\
n(\%)\end{array}$ & $\begin{array}{l}\text { May } \\
\mathrm{n}(\%)\end{array}$ & $\begin{array}{c}\text { November } \\
\mathrm{n}(\%)\end{array}$ & \\
\hline Number of evaluations & 14 & 18 & 47 & 21 & 22 \\
\hline Personal presentation & 99 & 98 & 95 & 92 & 97 \\
\hline Personal protective equipment & 100 & 100 & 85 & 77 & 100 \\
\hline Adequate isolations & 90 & 72 & 94 & 88 & 100 \\
\hline Adequate patient care in infection MI/VRE/Crisis & $\ldots$ & 82 & 89 & 98 & 93 \\
\hline General classification Mean & 94 & 85 & 92 & 93 & 95 \\
\hline
\end{tabular}

Related to periodicity of data collected by ASQNC, the service counted with a chronogram of predefined evaluation that occurred at least twice an year (one in the first and other in second semester) in 2009. In 2008 an evaluation routine was implemented, explaining why there are two consecutive testing evaluations; in 2010 there was only one evaluation in the first semester due to interdiction period in men and women surgical unit in the second semester.

In personal presentation, the care classification was considered adequate in all years described, with a lowest rate of $92 \%$.

In PPEs, the care classification was considered "desirable" in May 2009 and "borderline" in November 2009, with improvement in 2010.

Regarding isolations, care classification was considered "adequate" in October 2008 and May 2009, it was "desirable" in November 2009 and "borderline" in November 2008. In 2010, there was considerable improvement compared with previous years.

In patient care with multiresistant infection, Enterococcus resistant to vancomycin and in case of crisis (MI/VRE/ Crisis) it was desirable in November 2008 and adequate in the other periods.

In November 2008 in general mean the care was classified as desirable and adequate in other periods analyzed.

In 2010 all analyses of observation of universal precautions were considered adequate and safety, showing a improvement of care classification in the last year analyzed compared with the previous years.

Data in table 2 had general performance in men's surgery unit in October and November 2008, May and November 2009 and May and August 2010. 
Table 2. Comparative analysis of observation of universal precautions in men's surgical unit in October and November 2008, May and November 2009 and August 2010. Londrina, PR

\begin{tabular}{|c|c|c|c|c|c|c|}
\hline \multirow[b]{2}{*}{ Universal precautions } & \multicolumn{2}{|c|}{2008} & \multicolumn{2}{|c|}{2009} & \multicolumn{2}{|c|}{2010} \\
\hline & $\begin{array}{c}\text { October } \\
\mathrm{n}(\%)\end{array}$ & $\begin{array}{c}\text { November } \\
n(\%)\end{array}$ & $\begin{array}{l}\text { May } \\
\text { n(\%) }\end{array}$ & $\begin{array}{c}\text { November } \\
\mathrm{n}(\%)\end{array}$ & $\begin{array}{l}\text { April } \\
\mathrm{n}(\%)\end{array}$ & $\underset{\mathrm{n}(\%)}{\text { August }}$ \\
\hline Number of evaluations & 36 & 11 & 15 & 9 & 15 & 14 \\
\hline Personal presentation & 99 & 100 & 96 & 97 & 96 & 97 \\
\hline Personal protective equipment & 91 & 75 & 85 & 100 & 85 & 100 \\
\hline Adequate isolations & 77 & $\ldots$ & 95 & $\ldots$ & 95 & $\ldots$ \\
\hline Adequate patient care in infection MI/VRE/Crisis & 75 & 69 & 94 & 100 & 94 & 89 \\
\hline General classification Mean & 81 & 76 & 95 & 99 & 95 & 92 \\
\hline
\end{tabular}

Results in table 2 show that personal presentation and care classification was "safety" and "adequate" in all years described.

In use of personal protective equipments, care classification was "desirable" in May 2009, May 2010, "borderline" in November 2008 and "safety" in the last evaluation.

In isolations, classification care was "borderline" in October 2008 and "adequate" in May 2009 and May 2010.

In adequate patient care in multiresistant infection, Enterococcus resistant to vancomycin and in case of crisis (MI/VRE/Crisis), classification was "borderline" in October 2008, "insufficient" in November 2008 and "desirable" in August 2010. This item had the lower percentage of adequate care.

In general mean classification in October 2008 it was "desirable" and "borderline" in November 2008, in others years it was significantly improved.

\section{DISCUSSION}

Results of both Surgical Units had a general classification mean of observational analysis of universal precaution between "desirable" and "adequate", being "borderline" in November 2008 in the second unit. The analyses of universal precautions were collected in patients with infections who were isolated.

Isolation of patients was defined in 1960 by World Health Organization (WHO) and Pan American Health Organization (PAHO) as a segregation of infected people in a local environment under conditions to avoid direct and indirect transmission of infectious agents to susceptible individuals or to those that could transmit the disease to others ${ }^{(8,9)}$. According to WHO and PAHO, isolation of indentified patients also implies nosocomial infection control; however, health care professionals in charge must adhere to all measures or universal precautions in care to these patients in isolation.

The two units had different structures: The first one was recently renovated and had a physical isolation area adequate for patients with infectious disease acquired by contact. The second was an old structure, with an isolation area adapted for use in the structure and depending on needs. Despite the differences in the isolation area, results of both units were similar, suggesting that the structure itself may not interfere in the quality of care; however, other variables, such as educational background and continuing education, should be considered,

Data show that care classification regarding universal precautions in both institutions was considered adequate and safety in most of the assessments done. This could be because of the biosafey training of hospital employees, personal presentation with guidance of how to keep hair tied-up, nails short, and to not wear jewelry. The nursing team is required to wear a white uniform and closed shoes.

Training is given to nursing employees by the Nosocomial Infection Control Committee and Nursing Education and Research Division (NERD). The NICC also distributes informative handouts explaining the importance of strategies to control nosocomial infections and provide information on universal precautions.

An investigation carried out between 2000-2003 using data from final papers of a graduate program in 
biosafety and isolation in Rio de Janeiro revealed that $78.8 \%$ of studies assessed mentioned the existence of isolation policies in hospitals, manuals explaining universal precautions (57\%), and information distributed using posters $(28 \%)$ and signs $(14 \%)^{(5)}$.

All hospitals must have an NICC as stated in Ordinance $\mathrm{n}^{\circ}$ 2,616 May 12, 1998 by Minister of Health. Such committee is responsible to develop actions directed to prevent and control nosocomial infections and to guarantee patients and professionals safety ${ }^{(10)}$.

A study conducted in 25 hospitals in Bahia State showed that $76 \%$ of them had an NICC and $24 \%$ do not. All private hospitals had a formal committee, while only $66.7 \%$ of public hospitals had such a service. In this study $88 \%$ of institutions did not have guidelines on universal precautions ${ }^{(11)}$.

Universal precautions must be adopted during care of patients with infection or suspected to be infectious or contaminated. Therefore, it is fundamental for nursing teams to receive adequate training in effective control of nosocomial infections ${ }^{(1)}$. The responsible nurse must supervise, train and ensure that all PPEs are used by the team.

The responsible nurse should also be aware of updates in the field and supervise all actions in implementing universal precautions both to protect the team and to control nosocomial infections. It is legal and ethical responsibility not only of the institution but also of professionals ${ }^{(10)}$.

In the institution where this study was done, in addition to interventions made by NICC, the adherence of nursing professionals to universal precautions was evaluated. Such evaluations were conducted by the ASQNC, showing nursing directors' commitment in controlling nosocomial infection and protect nursing professionals.

A review carried out in 2008 pointed that $80 \%$ of studies on use of standard precautions to prevent and control hospital infection were done by nurses, which suggest that these professionals were interested in use of universal precautions to optimize quality of care for patients ${ }^{(6)}$.

Other study performed at a publically funded health institution in Minas Gerais showed that guidelines on universal precautions of isolated patients were provided to the nursing team by the responsible nurse in $71,4 \%$ of reports, by the nurse from the NICC in $59.5 \%$, by supervisors in $28.6 \%$, by patients' physicians in $19 \%$, by the physician from the NICC in $11.9 \%$ and by other professionals in $2.4 \%$. The study also showed a close relationship of nursing professionals with the responsible nurse and the nurse from the NICC, which was different if compared to other professionals especially for the wide communication among this category ${ }^{(12)}$.

Another study including technical and auxiliary nurses from the Emergency Service of Hospital Getúlio Vargas in Teresina-Piauí found that organizational and functional structure are points that suggest social representation of work conditions that seem to determine non-adherence of nursing professionals to technical and routines stated by prevention of hospital infections. That study also revealed that although many health care professionals recognize the technical and scientific characteristics of nosocomial infections, they often do not adopt measures of prevention and control ${ }^{(13)}$.

A different result was presented by a study including nurses from an internal medicine unit in Minas Gerais. In this study, health care professionals aware of risk situations in institutions implied the perception of susceptibility to acquire or disseminate bacterial resistance to multiple medications. In addition, the study added that more knowledgeable professionals had increased perception and to adherence to preventive measures for these patients ${ }^{(14)}$.

When it comes to nosocomial infections, prevention and control must be a habit of all health professionals. Total adherence of professionals is a permanent challenge that must continuously guide and motivate professionals ${ }^{(13)}$.

In the institutions in this study, the training conducted by NICC and NERD and evaluations by the ASQNC contributed to better results because based on current performance it became possible to establish goals and strategies for continuous improvement.

The responsible nurse for prevention of nosocomial infections must participate to encourage and motivate other nursing professionals to do the same. This direct supervision on care actions is fundamental to ensure quality and safety of care.

The ASQNC has the role of operational and retrospective audits. Audits were conducted by trainees because the service has only one nurse and one professional available for administrative tasks. Despite the fact that all trainees were instructed before conducting interviews, we believe that this approach constituted a limitation, because the students who conducted the interviews did not have adequate experience in collecting information.

\section{CONCLUSION}

Units assessed in this study had compromised biosecurity and patient isolation. However, as time passed, data showed improved performance each year. 


\section{REFERENCES}

1. Andrade D, Angerami EL. Reflections about cross infections in the transition to the third millennium]. Medicina (Ribeirão Preto). 1999; 32(4): 492-7. Portuguese.

2. Andrade GM. Custos da infecção hospitalar e o impacto na área da saúde. Brasília Méd. 2005; 45(1/2): 48-50.

3. Lima CD, Lopes MA, Gonçalves VM. [The nurse in the planning of the hospital physical space]. Rev Enferm Integr Ipatinga: Unileste-MG. 2010; 3(2): 484-93.Portuguese.

4. Silva MF, Santos BM. [Historical-organizational study about the hospital infection control committee of an university hospital]. Medicina (Ribeirão Preto). 2001; 34(2):170-6. Portuguese.

5. Scheidt KL, Rosa LR, Lima EF. [Biosafety actions implemented by hospital infections control committees]. Rev Enferm UERJ. 2006; 14(3):372-7. Portuguese.

6. Aguiar DF, Lima AB, Santos RB. [The use of the precautions pattern in the nursing attendance: retrospective study]. Esc Anna Nery Rev Enferm. 2008; 12(3): 571-5. Portuguese.

7. Haddad MC, Évora YD. [Nursing care quality: the view from a patient hospitalized in a public university hospital]. Cienc Cuid Saúde. 2008;7(Supl 1):45-52. Portuguese.

8. Organização Mundial da Saúde. Profilaxia das doenças transmissíveis. 9a ed. São Paulo: Melhoramentos; 1960.

9. Nichiata LY, Gir E, Takahashi RF, Ciosak SI. [Evolution of isolation in communicable diseases: knowledge in contemporary practice]. Rev Esc Enferm USP . 2004; 38(1): 61-70. Portuguese.

10. Fontana RT, Lautert L. [Ethical and legal aspects of hospital infection control: some reflections related to the nurse]. Cienc Cuid Saúde. 2008; 7(4): 546-50. Portuguese.

11. Penteado MS, Oliveira TC. [Biosecurity infrastructure for biological agents in hospitals from the south of Bahia State, Brazil]. Rev Bras Enferm.. 2010; 63(5): 699-705. Portuguese.

12. Moura JP. A adesão dos profissionais de enfermagem ás precauções de isolamento na assistência aos portadores de micro-organismos multirresistentes [dissertação]. Ribeirão Preto: Universidade de São Paulo; 2004.

13. Santos AM, Cabral LA, Brito DS, Madeira MZ, Costa e Silva ME, Carvalho e Martins MC. [The social representations of hospital-acquired infections elaborated by nursing professionals]. Rev Bras Enferm. 2008; 61 (4): 441-6. Portuguese.

14. Moura JP, Gir E. Nursing staff knowledge of multi-resistant bacterial infections. Acta Paul Enferm. 2007;20(3):351-6. 